University of Wollongong

Research Online

Faculty of Law, Humanities and the Arts Papers (Archive)

$1-1-2016$

Ocean Diplomacy: The Pacific Island Countries' Campaign to the UN for an Ocean Sustainable Development Goal

Genevieve Quirk

University of Wollongong, gcq691@uowmail.edu.au

Quentin A. Hanich

University of Wollongong, hanich@uow.edu.au

Follow this and additional works at: https://ro.uow.edu.au/lhapapers

Part of the Arts and Humanities Commons, and the Law Commons

Research Online is the open access institutional repository for the University of Wollongong. For further information contact the UOW Library: research-pubs@uow.edu.au 


\title{
Ocean Diplomacy: The Pacific Island Countries' Campaign to the UN for an Ocean Sustainable Development Goal
}

\author{
Abstract \\ In this article we examine how Pacific Island Countries (pics) successfully championed a stand-alone \\ Ocean Sustainable Development Goal (sdg) goal at the United Nations (un). We analyse how the un \\ Post-2015 development process provided pics with a unique opportunity to use their experience with \\ collective diplomacy and regional oceans governance to propose this international goal. In this article we \\ establish how pics' national and regional quest to strengthen their sovereign rights over marine resources \\ motivated their diplomatic efforts for an Ocean sdg. The campaign was a significant political \\ achievement, positioning these Large Ocean Island States (lois) as global ocean guardians. We critically \\ evaluate the effectiveness of the pics' diplomatic campaign to secure an international commitment for an \\ Ocean sdg. The pics' advocacy for Goal 14 under Agenda 2030 has enhanced their political effectiveness \\ in the un by improving their recognition by other States as leaders in oceans governance. We suggest \\ their Ocean sdg campaign forms part of a distinct and continuing brand of oceans diplomacy from \\ Oceania.

\section{Keywords} \\ diplomacy:, pacific, island, ocean, countries', goal, campaign, un, sustainable, development

\section{Disciplines} \\ Arts and Humanities | Law

\section{Publication Details} \\ Quirk, G. \& Hanich, Q. (2016). Ocean Diplomacy: The Pacific Island Countries' Campaign to the UN for an \\ Ocean Sustainable Development Goal. asia-pacific journal of ocean law and policy, 1 (1), 68-95.
}




\title{
Ocean Diplomacy: The Pacific Island Countries' Campaign to the $\mathrm{UN}$ for an Ocean Sustainable Development Goal
}

\author{
Genevieve Quirk and Quentin Hanich \\ ANCORs, University of Wollongong, Australia \\ gcq691@uowmail.edu.au; hanich@uow.edu.au
}

\begin{abstract}
In this article we examine how Pacific Island Countries (PICs) successfully championed a stand-alone Ocean Sustainable Development Goal (SDG) goal at the United Nations (UN). We analyse how the UN Post-2015 development process provided PICs with a unique opportunity to use their experience with collective diplomacy and regional oceans governance to propose this international goal. In this article we establish how PICs' national and regional quest to strengthen their sovereign rights over marine resources motivated their diplomatic efforts for an Ocean SDG. The campaign was a significant political achievement, positioning these Large Ocean Island States (LOIS) as global ocean guardians. We critically evaluate the effectiveness of the PICs' diplomatic campaign to secure an international commitment for an Ocean SDG. The PICs' advocacy for Goal 14 under Agenda 2030 has enhanced their political effectiveness in the UN by improving their recognition by other States as leaders in oceans governance. We suggest their Ocean SDG campaign forms part of a distinct and continuing brand of oceans diplomacy from Oceania.
\end{abstract}

* BSc, MEnvLaw, PhD Candidate, Australian National Centre for Ocean Resources and Security (ANCORS), University of Wollongong, NSW, 2500, Australia. The author would like to thank Professor Clive Schofield and the reviewers for their review of the manuscript and the Global Challenges PhD Scholars Program for funding the research.

** Dr, Associate Professor, Australian National Centre for Ocean Resources and Security (ANCORS), University of Wollongong, NSW, 2500, Australia. 


\section{Keywords}

diplomacy - Pacific Island Countries - Sustainable Development Goals - Small Island Developing States - ecological integrity

The United Nations SD Gs aim to build on the Millennium Development Goals (MDGs) and provide a pathway to reconcile human development within ecological limits. ${ }^{1}$ Global drivers of environmental change like climate change, ocean acidification and biodiversity loss threaten Oceania's marine ecosystems. ${ }^{2}$ The oceans are integral to the economy, diverse cultures and food security of Pacific Islanders. The deteriorating health of marine ecosystems demands a new system of international cooperation toward improved governance of ocean resources. In this article we analyse the successful diplomatic campaign by Pacific Island Countries (PICs) for Goal14 'to conserve and sustainably use the oceans, seas and marine resources for sustainable development' under Transforming Our World: the 2030 Agenda for Sustainable Development (Agenda 2030). ${ }^{3}$

PICs consider an Ocean SDG an advance on the international support and attention lacking under the MDGs for global ocean issues crucial to protecting the economic value of their marine resources. ${ }^{4}$ Global environmental change demands a re-evaluation of the governance architecture responsible for the global drivers of deleterious environmental change. As the dominant forces for ecosystem degradation lie beyond Oceania, ${ }^{5}$ the inclusion of all States under Agenda 2030 provides a unique opportunity to address these global drivers. This article demonstrates the significance of the PIC diplomatic campaign for

1 D Griggs, et al, 'Sustainable development Goals for People and Planet' (2013) 495:7441 Nature 305-307, at 305 .

2 Ove Hoegh-Guldberg, et al, 'Coral Reefs under Rapid Climate Change and Ocean Acidification' (2007) 318:5857 Science 1737-1742, at 1741.

3 General Assembly Resolution 70/1, Transforming Our World: The 2030 Agenda for Sustainable Development, A/RES/70/1 (25 September 2015), at 23.

4 PIfSa, 'Forum Communiqué, Annex B Palau Declaration on "The Ocean: Life and Future": Charting a course to sustainability' (presented at $45^{\text {th }}$ Pacific Island Forum, Koror, 29-31 July 2014), at 1.

5 Hendrik Selles, 'The Relative Impact of Countries on Global Natural Resource Consumption and Ecological Degradation' (2013) 20:2 International Journal of Sustainable Development \& World Ecology, 97-108, at 98. 
an Ocean SDG at the UN to improve the governance of ocean ecological systems for Oceania and the global community.

This article establishes the PIC campaign for an Ocean SDG as part of a coordinated multilateral foreign policy for strengthened sovereign rights over marine natural resources. Their campaign for an Ocean SDG under the UN post-2015 development agenda presents a transformational shift from the terrestrial and aid for development focus of the MDGs. We demonstrate how the success of the PIC campaign has empowered PICs political engagement at the UN. This has occurred through their re-identification from Small Island Developing States (SIDS) to Large Ocean Island States (LOIS), reassertion of maritime guardianship as traditional custodians of vast oceanscapes, and as contemporary leaders in oceans governance at the regional scale. We suggest the PICs' regional solidarity and effective advocacy for Goal 14 under Agenda 2030 forms part of a distinct and continuing brand of oceans diplomacy from Oceania.

In section II we examine the historical and contemporary challenges to sovereign control of marine natural resources in Oceania. Section II follows with how their collective diplomacy evolved to meet the challenge global environmental interdependence presented to the traditional legal order of sovereign supremacy. Section IV examines the operation of oceanscape-scale governance frameworks in the establishment of regional positions in global oceans governance. Section v documents the power asymmetries with external states and the importance of strengthening sovereign control over marine natural resources in the context of the Pacific tuna fishery. Section VI analyses the operation and influence of PIC collective diplomacy to the UN in their campaign for a stand-alone Ocean SDG in the post-2015 development process. Section VII considers approaches from existing and emerging areas of environmental law in a reflection on Goal 14's capacity to achieve the PIC aim of preserving ocean ecosystem integrity. In section VIII we propose the unity of Pacific sids on ocean issues is sourced from a shared Oceanian identity. In conclusion, we use these sections of the article to demonstrate collective diplomacy for an Ocean SDG was significant for PICs, positioning these countries as global marine stewards to increase their influence in UN negotiations.

Global environmental interdependence requires States to find new diplomatic solutions to balance their sovereign rights and international duties for the governance of ocean resources. Globalization through trade, investment and 
aid create linkages through which state and non-state actors exert significant control and influence over negotiations on the exploitation of marine natural resources. Kerr and Wiseman define sovereignty as: ${ }^{6}$

The condition whereby a state claims ultimate legal authority over defined territory and the right to represent the people of that territory in the international community. It is the extent to which a polity is under no external pressure from other political entities regarding any aspect of its behaviour or decision making.

Power asymmetries between PICs and these state and non-state actors have undermined the sovereign legal authority of these polities by influencing decisions about the use of marine natural resources within their territory. ${ }^{7}$

For Pacific Island Countries and Territories (PICTs) foreign incursions and exploitation of adjacent marine natural resources undermined the ideal and promise of sovereign authority and equality under the 1954 UN Charter. ${ }^{8}$ These incursions challenged the ability of PICTs to secure and protect their surrounding marine natural resources. Securing and extending sovereign rights over marine natural resources was a key aspiration of PICTs. ${ }^{9}$ The 1962 UNGA resolution on the permanent sovereignty over natural resources ${ }^{10}$ was important for PICTs who sought emancipation from exploitation of marine natural resources at odds with their national interests.

The delimitation of a States marine sovereign space was fundamental to PICTs control over adjacent marine resources and a challenge for attempts to codify an international instrument to govern the oceans. The maritime space is vital to international peace and security and the functioning of the global ecosystem. The immense potential for international cooperation through a united approach to oceans governance was realised with the United Nations Convention on the Law of the Sea 1982 (LOSC).

6 Pauline Kerr and Geoffrey Wiseman, Diplomacy in a Globalizing World, (Oxford University Press, 2012), at 358.

7 Stewart Firth, 'The Pacific Islands and the Globalization Agenda' (2000) 12(1) The Contemporary Pacific, 177-192, at 177 .

8 United Nations, Charter of the United Nations, 24 October 1945, 1 UNTS XVI, available at http://www.refworld.org/docid/3ae6b393o.html [UN Charter], Art 2(1).

9 Tuiloma Neroni Slade, 'Making of International Law: The Role of Small Island States', (2003) 17 The Temple International and Comparative Law Journal, 531-544, at 535.

10 General Assembly Resolution 1803 (XVII), Permanent Sovereignty over Natural Resources, A/5217 / 17 UN GAOR Supp (No17) (14 December 1962), at 15 . 
The LOSC was negotiated and adopted by the third United Nations Conference on the Law of the Sea (UNCLOS III 1973-1982) which coincided with an intense period of decolonization in Oceania. During UNCLOS III PICs advocated for the acquisition of extensive sovereign rights over non-living and living marine resources." The final text accorded PICs with substantial agency over their marine resources through an EEZ to $200 \mathrm{~nm} .{ }^{12}$ The declared maritime area within the Pacific Island Region represents approximately 30 percent of the global area under national jurisdiction. ${ }^{13}$ The Losc recognises the sovereign rights of coastal states "for the purpose of exploring and exploiting, conserving and managing the natural resources" and to "determine the allowable catch of the living resources" in their EEz. ${ }^{14}$

Despite their diverse stages of development and decolonization, PICTs' remain alike in their continuing vulnerability to and direction by the power configuration of outside forces..$^{15}$ The liberty and power that had characterised sovereign states was a key aspiration of campaigns for independence across Oceania. However, in Oceania the emancipation from colonial rule coincided with a shift from a State-based system of global governance to the increasing authority of non-government institutions and corporate and civil non-government organisations in determining the global order. PICs face these new potential challengers to their natural resource sovereignty with the interdependent threats of food security and environmental degradation. Section $v$ examines the impacts of these power asymmetries in the context of the regional tuna fishery.

Collective oceans diplomacy can best be understood in the context of the historical political settlement for Oceania's premier regional organisation,

11 Michael Powles, 'Making Waves in the Big Lagoon: The Influence of Pacific Island Forum Countries in the United Nations' (2002) 2 Revue Juridique Polynesienne, 59-76, at 60.

12 Anthony Bergin, 'Political and Legal Control over Marine Living Resources-Recent Developments in South Pacific Distant Water Fishing' (1994) 9 International Journal of Marine \& Coastal Law, 289-310, at 289.

13 Andrew Wright, Natasha Stacey and Paula Holland, 'The Cooperative Framework for Ocean and Coastal Management in the Pacific Islands: Effectiveness, Constraints and Future Direction', (2006) 49:9 Ocean \& Coastal Management, 739-763, at 740.

14 UNCLOS, Arts 56 \& 61.

15 Stephen Levine, 'The Experience of Sovereignty in the Pacific: Island States and Political Autonomy in the Twenty-First Century', (2012) 50:4 Commonwealth \& Comparative Politics, 439-455, at 445-446. 
the Pacific Island Forum (Forum). In 1971 the organisation was formed to address the inequalities and limits on political discussions undermining the selfdetermination of PICs, and the Pacific Territories straining for their independence from colonial powers. ${ }^{16}$ Members of the Forum were required to have attained independence from colonial powers for admission and its membership evolved with the increasing number of decolonised PICs. The Forum worked to serve the developing countries and strengthen regional integration, and matured into a forum for collective diplomacy. ${ }^{17}$

PICs were among the first architects of formal oceans governance at the regional scale. At UNCLOS III, PICs advocated as a group ${ }^{18}$ for regional arrangements under the law of the sea. ${ }^{19}$ Reflecting on the informal composite negotiating text ${ }^{20}$ during UNCLOS III a number of academics advocated for the benefits of a regional approach to the law of the sea. ${ }^{21}$ Janis identified the historical, geographical accord for and mutual political, economic and security benefits of regional cooperation in matters pertaining to the law of the sea. ${ }^{22}$ Of further relevance for Oceania, regional coordination of legal claims improved cooperation within the region and increase the group's influence in their dealing with states outside their region. ${ }^{23}$

At the 1976 Forum PICs recognised the benefits of regional coordination and agreed to consult with one another in the establishment of their 200nm EEZ, harmonise fisheries policy across the region and cooperate in negotiations

16 Greg Fry, 'Recapturing the Spirit of 1971: Towards a New Regional Political Settlement in the Pacific' (Discussion Paper State, Society \& Governance in Melanesia Program ANU 2014).

17 Grey Fry and Sandra Tarte, The New Pacific Diplomacy (ANU Press, 2015), at 48.

18 The Oceania Group was an informal regional group within in UNCLOS consisting of Australia, the Cook Islands, Fiji, Micronesia, Nauru, New Zealand, Papua New Guinea, Tonga, and Western Samoa.

19 Fredrick L Ramp, 'Regional Law of the Sea: A Proposal for the Pacific', (1977) 18 Virginia Journal of International Law, at 121.

20 Third United Nations Conference on the Law of the Sea, Informal Composite Negotiating Text, A/CONF.62/WP.10 (15 July 1977).

21 Mark W Janis, 'Roles of Regional Law of the Sea', (1975) 12:3 San Diego Law Review, at 553; Michael Hardy, 'Regional Approaches to Law of the Sea Problems: The European Community', (1975) 24:2 International and Comparative Law Quarterly, 336-348; Robert B Krueger and Myron H Nordquist, 'Evolution of the 200-Mile Exclusive Economic Zone: State Practice in the Pacific Basin' (1978) 19 Virginia Journal of International Law, at 321; Lewis M Alexander, 'Regional Arrangements in the Oceans', (1977) 71 American Journal of International Law, at 84 .

22 Mark WJanis, 'Roles of Regional Law of the Sea', (1975) 12:3 San Diego Law Review, 553-562, at 553 .

23 Ibid. 
with external fishing states. ${ }^{24}$ This demonstrates the responsiveness of PICs to the power asymmetries with external states for their claims on marine natural resources. PICs advocacy for regional arrangements under the law of the sea and multilateral collaboration for a regional fishing policy were early diplomatic tactics to enhance their sovereign rights over marine natural resources.

The United Nations Conference on the Human Environment (UNHCE) 1972 was important in recognising the interlinkages between the environment and development and articulating the global environmental responsibility for the protection of the environment. ${ }^{25}$ This responsibility challenged the traditional legal order of sovereign supremacy to acknowledge, adapt and evolve to prevent further environmental damage. ${ }^{26}$ Together the PICs responded with the development of a regional governance instrument the Convention on Conservation of Nature in the South Pacific 1976. The PICs were also early architects of a regional instrument under the UNEP Regional Seas Programme with the Convention for the Protection of the Natural Resources and Environment of the South Pacific Region (1986). ${ }^{27}$ Rochette et al and Warner, Gjerde and Freestone also endorse a regional approach as an important means to address the fragmented coordination of oceans governance. ${ }^{28}$

Cicin-Sain and Knecht, Van Dyke and Osmundsun consider efforts to meet obligations under the LosC through regional instruments, such as the Convention for the Protection of the Natural Resources and Environment of the South Pacific Region (1986), contribute to form a new regional regime for oceans governance in Oceania. ${ }^{29}$ The next section analyses the newest regional

24 South Pacific Forum, Forum Communiqué, Nauru, 26 - 28 July 1976, at 8; R Kearney, 'The Law of the Sea and Regional Fisheries Policy' (South Pacific Commission Occasional Paper No 2, 1977).

25 The United Nations Conference on the Human Environment, Declaration of the United Nations Conference on the Human Environment, A/Conf.48/14/Rev (16 June 1972).

26 Susan H Bragdon, 'National Sovereignty and Global Environmental Responsibility: Can the Tension be Reconciled for the Conservation of Biological Diversity', (1992) 33:2 Harvard International Law Journal, 381-392, at 384.

27 Convention for the Protection of the Natural Resources and Environment of the South Pacific Region, adopted 24 November 1986 (entered into force 22 August 1990).

28 Robin Warner, K Gjerde, and David Freestone, 'Regional Governance for Fisheries and Biodiversity', in sм Garcia, J Rice and A Charles (eds), Governance of Marine Fisheries and Biodiversity Conservation: Interaction and Coevolution (John Wiley and Sons, 2014), 211-224; Julien Rochette, et al, 'Regional Oceans Governance Mechanisms: A Review', (2015) 6o Marine Policy, 9-19.

29 Biliana Cicin-Sain and Robert W Knecht 'The Emergence of a Regional Ocean Regime in the South Pacific', (1989) 16 Ecology Law Quarterly, 171-215, at 191; Jon M Van Dyke 'Regionalism, Fisheries and Environmental Challenges in the Pacific' (2004) 6 San Diego International Law Journal, at 143; Lori Osmundsen, 'Paradise Preserved-The Contribution of the 
instruments for oceans governance at the oceanscape scale as they relate to the PIC campaign for an Ocean SDG.

\section{Oceanscape Scale Governance}

In 2002, the sixteen independent and self-governing states in Oceania of the Forum endorsed the Pacific Island Regional Ocean Policy (PIROP). ${ }^{30}$ The PIROP forms the central reference for the establishment of regional positions in international oceans governance and its implementing framework aims to maintain the health of the ocean using an integrated transboundary approach through the harmonization of international and regional instruments and institutions. ${ }^{31}$ The subsequent Framework for a Pacific Oceanscape (FPO $)^{32}$ provides a renewed effort to implement the PIROP, and was designed to address the institutional challenges experienced in the coordination of regional ocean governance. ${ }^{33}$

Regional oceans governance aspires to address the cumbersome nature of global governance while encompassing a sufficient scale of ecological ocean processes for governance interventions to be meaningful for ecosystem function. The strong political commitment from PIC leaders for the PIROP make it a powerful instrument as does both the scale of its oceans coverage and its principle to preserve ecosystem integrity as driven by regional-scale ecosystem processes. ${ }^{34}$ This legal/ecological accordance is a quality envisioned for effective international oceans law as early as $1925^{35}$

UNEPs Regional Seas Programme in an example of one of the first endeavours to align governance at the scale of the ocean ecosystem. Young et al

SPREP Convention to the Environmental Welfare of the South Pacific' (1992) 19:4 Ecology Law Quarterly, 727-793, at 780 .

$30 \quad$ PIFs, Forum Communique: Annex 2 Pacific Island Regional Ocean Policy (33rd Pacific Islands Forum, Fiji, 15-17 August 2002), at 12-18.

31 PIFs, Pacific Islands Regional Ocean Policy and the Framework for Integrated Strategic Action (Noumea: Secretariat of the Pacific Community, 2005), at 3.

32 PIFs, Framework for a Pacific Oceanscape (Marine Sector Working Group, Council of Regional Organisations of the Pacific, 2010).

33 C Pratt and H Govan, Our Sea of Islands, Our livelihoods, Our Oceania: Framework for a Pacific Oceanscape: A Catalyst for Implementation of Ocean Policy (Report prepared for the CROP Marine Sector Working Group, 2010).

34 PIFs, supra note 35 , at 6.

35 J Suarez, 'Report on the Exploitation of Products of the Sea', in Shabtai Rosenne (ed) League of Nations Committee of Experts for the Progressive Codification of International Law (1925-1928), Vol 2 (Oceana Publications, 1972), 146-152, at 147. 
consider the large-scale spatial management of marine ecosystems crucial to the ecological crisis confronting our oceans. ${ }^{36}$ Telesetsky envisions the use of 'ecoscape thinking' citing scale as a critical element to successful governance and restoration of marine ecosystems. ${ }^{37}$ The PIROP and FPO significantly broaden the scale envisaged by these authors from large marine ecosystems to the 'oceanscape'. Yet as policy frameworks for regional coordination the PIROP and FPO only somewhat address the need for a precise and robust corresponding legal instrument for large-scale oceans governance. ${ }^{38}$

In section II we examined how the historical motivations behind regional solidarity for oceans governance have been a central driver for cooperation and coordination between PICs. Regional-scale governance of transboundary marine natural resources, however, retains the challenges of the accountability ${ }^{39}$ and legitimacy ${ }^{40}$ inherent to agency beyond the state ${ }^{41}$ yet is increasingly popular for both environment and development donors. ${ }^{42}$ In Oceania the complex institutional framework for oceans governance ${ }^{43}$ is of consequence for the governability of ocean resources at this scale. Questions raised on

36 Oran R Young, et al, 'Solving the Crisis in Ocean Governance: Place-Based Management of Marine Ecosystems', (2007) 49:4 Environment: Science and Policy for Sustainable Development, $20-32$.

37 Anastasia Telesetsky, 'Restoration and Large Marine Ecosystems: Strengthening Governance for An Emerging International Regime Based on Ecoscape Management', (2013) 35 University of Hawaii Law Review, at 735 .

38 Wang Hanling, 'Ecosystem Management and Its Application to Large Marine Ecosystems: Science, Law and Politics', (2004) 35:1 Ocean Development \& International Law, at 6o; Martin H Belsky, 'Management of Large Marine Ecosystems: Developing a New Rule of Customary International Law', (1985) 22 San Diego Law Review, 733-763.

39 Juan L Suárez de Vivero, Juan C Rodríguez Mateos, and David Florido del Corral, 'Geopolitical Factors of Maritime Policies and Marine Spatial Planning: State, Regions and Geographical Planning Scope', (2009) 33:4 Marine Policy, 624-634.

40 Daniel Bodansky, 'The Legitimacy of International Governance: A Coming Challenge for International Environmental Law?', (1999) American Journal of International Law. 596-624.

41 Frank Biermann, "Earth System Governance" As a Crosscutting Theme of Global Change Research', (2007) 17:3 Global Environmental Change, 326-337.

42 Robin Mahon, et al, 'Governance Characteristics of Large Marine Ecosystems', (2010) 34:5 Marine Policy, 919-927; Pedro Fidelman, et al, 'Governing Large-Scale Marine Commons: Contextual Challenges in the Coral Triangle', (2012) 36:1 Marine Policy, 42-53.

43 Andrew Wright, Natasha Stacey and Paula Holland 'The Cooperative Framework for Ocean and Coastal Management in the Pacific Islands: Effectiveness, Constraints and Future Direction', (2006) 49:9 Ocean \& Coastal Management, 739-763, at 744. 
governability of marine systems at large scales ${ }^{44}$ also implicate the prudence of directing funding resources and capacity building for governance at this scale.

Giraud-Kinley, Chasek and Osmundsen provide rigorous critiques of the challenges of implementing multilateral environmental agreements with existing Pacific institutional architecture, capacity and resources. ${ }^{45}$ Tutangata and Power highlight the importance of the inter-agency collaboration under the Council of Regional Organisations of the Pacific in maintaining a functional framework for the coordination of diverse institutions. ${ }^{46}$ The Marine Sector Working Group is responsible for this coordination between those agencies with a mandate for oceans governance.

The implementation of the FPO established the Pacific Ocean Commissioner (POC) to improve high-level representation and provide dedicated advocacy on oceans issues for the region. The POC is supported by the Office of the Pacific Ocean Commissioner, which is gaining recognition for its role in improving coordination on regional oceans governance issues with the multiple agencies with an oceans mandate through the MSWG. The success of this coordination of regional ocean issues is manifest in the clear mandate for a stand-alone Ocean SDG from the region to United Nations Ambassadors and Permanent Representatives to the UN. ${ }^{47}$ The UNSG recognised the Pacific Forum leaders as ocean stewards and commended the Forum campaign for an Ocean SDG. ${ }^{48}$

Manoa documents the rise of the Pacific sids as the primary advocacy group at the UN for PICs. ${ }^{49}$ A finding supported in Gruby and Campbell's analysis of PIC global environmental governance negotiations. ${ }^{50}$ Manoa's

44 Svein Jentoft, 'Limits of Governability: Institutional Implications for Fisheries and Coastal Governance', (2007) 31:4 Marine Policy, 36o-370.

45 Robin Mahon, et al, 'Governance Characteristics of Large Marine Ecosystems', (2010) 34:5 Marine Policy, 919-927; Pamela S Chasek, 'Confronting Environmental Treaty Implementation Challenges in the Pacific Islands' (Pacific Island Policy East-West Center, 2010); Lori Osmundsen, 'Paradise Preserved-The Contribution of the SPREP Convention to the Environmental Welfare of the South Pacific', (1992) 19:4 Ecology Law Quarterly, 727-793.

46 Tamari'i Tutangata and Mary Power, 'The Regional Scale of Ocean Governance Regional Cooperation in the Pacific Islands', (2002) 45:11 Ocean \& Coastal Management, 873-884. PIFSa 'Forum Communiqué, Annex B Palau Declaration on "The Ocean: Life and Future”: Charting a Course to Sustainability' ( $45^{\text {th }}$ Pacific Island Forum, Koror, 29-31 July 2014), at 2.

48 United Nations, Secretary General, Secretary-General's Remarks at Meeting with Pacific Islands Forum Leaders, 26 September 2014, at 1.

49 Fulori Monoa, 'The New Pacific Diplomacy at the United Nations: The Rise of the Psids'. in G Fry and S Tarte (eds), The New Pacific Diplomacy (ANU Press, 2016), 213-234, at 233.

5o Rebecca Gruby and Lisa Campbell, 'Scalar Politics and the Region: Strategies for Transcending Pacific Island Smallness on a Global Environmental Governance Stage', (2009) 45:9 Environment and Planning A, 2046-2063, at 206o. 
analysis defines the operation of the Pacific sIDs group at the UN distinct from Forum members Australia and New Zealand. She cites differing interests with Australia and New Zealand as one of the reasons for the PICs' collective advocacy at the UN along with the benefits of collaborative working arrangements to address the resourcing and capacity challenges of Pacific Island missions to the UN. In this article we have shown the solidarity between Forum members for a common oceans governance framework and focus on the interventions of Pacific Island Countries from within the Forum group (excluding Australia and New Zealand). In section vi we chart the efforts of advocacy for an Ocean SDG as a uniquely PICs campaign which supports Manoa's assertion of Pacific sIDS as the PICs primary advocacy grouping. We substantiate this claim with evidence of the operation of the Pacific sIDs as a discrete group from the UN SIDS in the Ocean SDG campaign to the UN.

The continuing focus by PICs on global ocean issues at the UN signals an investment and commitment to the future of collective ocean diplomacy for the PICs. For example, the region will begin a training program in January 2016, the UN Pacific SIDS Fellowships on the Ocean and Seas, which is intended to train a new generation of PIC delegates at the UN. ${ }^{51}$ Similarly, the region will subsequently host the 2017 High-level United Nations Conference to Support the Implementation of Sustainable Development Goal 14 (Conserve and Sustainably Use the Oceans, Seas and Marine Resources for Sustainable Development) to coincide with World Oceans Day. ${ }^{52}$ The Conference provides a significant platform to showcase oceans governance by the Pacific at this conference on accountability for the delivery of Goal 14.

\section{Power Asymmetries with External States}

A stand-alone Ocean SDG could provide the PICs with a mechanism to strengthen their sovereignty and control over marine natural resources. Sovereignty and control could be strengthened through global commitments

$5^{1} \quad$ United Nations, General Assembly, Statement by Dr T Suka Mangisi, Deputy Permanent Representative and Charge d'Affaires ai, Permanent Mission of the Kingdom of Tonga to the United Nations, Chair of the Pacific Island Developing States (PSIDS) on Agenda Item 82: United Nations Programme of Assistance in the Teaching, Study, Dissemination and Wider Appreciation of International Law at the Sixth Committee of the $70^{\text {th }}$ Session of the United Nations General Assembly (23 October 2015), at 2.

52 United Nations, General Assembly, United Nations Conference to Support the Implementation of Sustainable Development Goal 14: Conserve and Sustainably Use the Oceans, Seas and Marine Resources for Sustainable Development, A/C.2/70/L.3/Rev.1 (2 December 2015). 
to restore marine biodiversity, constrain exploitation, maintain productivity, sustain PIC livelihoods and retain the value of territorial marine natural resources for emerging PIC trade initiatives. It is recognized here that international duties for environmental protection themselves can also limit sovereign rights over natural resources - to which targets under an ocean SDG could contribute. The Pacific tuna fishery highlights the importance of a universal development agenda for the transnational challenge of managing shared natural resources under the SDGs.

Control over healthy marine natural resources remains pivotal to the empowerment and economic development of PICs. ${ }^{53}$ Oceania is the source for over 60 percent of the world's tuna catch sustaining a $\$$ Us 5.8 billion fishery. 54 Most of the fishing is undertaken by foreign industrial fishing vessels whose fishing access fees provide 10-6o percent of all government revenue for six PICs and less for those countries with more diversified economies. ${ }^{55}$ Even so the industrial fishing fleets from outside Oceania return a small fraction of the financial benefits to the source countries. ${ }^{56}$

Development opportunities from these marine resources are dependent on PIC's ability to secure and administer allocation to their marine resources under regional institutions. States involved in the tuna fishery are deadlocked on the fisheries access allocation system as PICs resist efforts to reopen allocation discussions, which could undermine the progress on their allocated proportion of the catch ${ }^{57}$ and potentially erode their sovereign rights over marine natural resources. The ideal and promise of sovereign powers 'on equal terms' 58 is not

53 Transform Aqorau, 'Moving Towards a Rights-Based Fisheries Management Regime for the Tuna Fisheries in the Western and Central Pacific Ocean' (2007) 22:1 The International Journal of Marine and Coastal Law, 125-142.

54 Peter Williams and Peter Terawasi, Overview of Tuna Fisheries in the Western and Central Pacific Ocean, Including Economic Conditions, 2014 Scientific Committee Eleventh Regular Session Pohnpei, Federated States of Micronesia, WCPFC-SC11-2014/GN WP-1 Rev 1 (28 July 2015), at 2.

55 Secretariat of the Pacific Community, 'Pacific Island Communities and Climate Change', (2014) 24 Policy Briefing, 1-5, at 1.

56 Fulitua Siaosi, et al, 'Fisheries development strategy for developing Pacific Island Countries: Case study of Tuvalu', (2012) 66 Ocean \& Coastal Management, at 29.

57 Hannah Parris and Alex Lee, 'Allocation Models in the Western and Central Pacific Fisheries Commission and Implications for Pacific Island States', in Quentin Hanich and Martin Tsamenyi (eds), Navigating Pacific Tuna Fisheries Instruments in the Western and Central Pacific Ocean (University of Wollongong, 2009), 250-283, at 250.

58 Pahuja Sundhya, Decolonizing International Law: Development Economic Growth and the Politics of Universality (Cambridge Press, 2011), at 135. 
reflected in PICs' ability to profit from the reallocation of fishing rights under the LOSC. 59

In response, a sub-regional group, the Parties to the Nauru Agreement, ${ }^{60}$ aimed to secure greater economic benefits from tuna exploitation by coordinating and harmonising access conditions to their exclusive economic zones (EEZs). They used a novel arrangement to extend their licensing conditions from member EEZs into the high seas. ${ }^{61}$ By limiting fishing in the high seas these States improved their control over the spatial distribution of fishing effort within their EEzs and enhanced their sovereign rights over marine resources.

Analysis of the PIC Ocean SDG Campaign

In this section we analyse the diplomatic efforts by PICs for improved oceans governance in their campaign to secure a stand-alone Ocean SDG. We follow the PIC interventions made at official multilateral fora relevant to the United Nations post-2015 development agenda chronologically between 2012-2015. We critically evaluate the contribution of the PIC campaign during the post2015 development process to empower their collective diplomacy.

The United Nations Conference on Sustainable Development 2012 outcome document, The Future We Want, mandated an Open Working Group (owG) to propose SDGs to the $68^{\text {th }}$ session of the UNGA. The PICs were successful in their campaign at the OWG, which produced a proposal with seventeen SDGs including a stand-alone Ocean SDG. The campaign continued in 2015 to retain this stand-alone Ocean SDG as Goal 14 in Agenda 2030.

In August 2012 the Pacific leaders at the Forum endorsed the annual theme of PICs as Large Ocean Island States with a leading role in Pacific Ocean management. In the same month the Small Islands Developing States (sIDs) integrated an enabling cooperation framework for the Barbados Programme of Action and Mauritius Strategy for the Further Implementation of the Programme of Action for the Sustainable Development of Small Island Developing States. This recognised SIDS as LOIS and proposed a stand-alone Ocean SDG.

59 Rachel Schurman, 'Tuna Dreams: Resource Nationalism and the Pacific Islands Tuna Industry', (1998) 29:1 Development and Change, 107-136, at 109.

6o Nauru Agreement Concerning Cooperation in the Management of Fisheries of Common Interest, adopted 11 February 1982 (entered into force 4 December 1982).

61 A Third Arrangement Implementing the Nauru Agreement Setting Forth Additional Terms and Conditions of Access to the Fisheries Zones of the Parties, adopted 16 May 2008. 
This cooperation was of great significance to the PIC campaign as it provided a larger coalition of sIDS in solidarity with the Pacific SIDs for an Ocean SDG.

The PIC campaign for an Ocean SDG demonstrates how by reframing their sovereign space as LOIS the PICS change firstly their perceived power as microstates and secondly better positions them to broaden negotiations from the terrestrial focus of the MDGs. Gruby and Campbell established how PICs' collective promotion of their vast ocean scale is a successful political strategy for empowerment in UN negotiations on global environmental governance. ${ }^{62}$ The campaign for a stand-alone Ocean SDG illustrates this collective promotion on oceans governance in operation at the UN in the post-2015 development process.

In September 2012 at the UNGA Inoke Kubuabola, Minister for Foreign Affairs and International Cooperation of Fiji, characterized the oceans as their 'lifeblood' and source of sustainable development: ${ }^{63}$

Like all islands nations, Fiji relies on the ocean and its resources as our economic life blood and source of sustainable development. While fish and other marine living resources have been vital to Fijis economy and livelihood, we believe that our efforts to explore deep sea mineral resources present greater potential, provided that a precautionary approach with regard to environmental sustainability is ensured.

Anote Tong, President of Kiribati, describes his country as a LOIS and emphasizes the fundamental role of the ocean to their sustainable development, the achievement of the MDGs, and its importance for the wellbeing of the global community. President Tong articulates the ocean as a key instrument for empowerment and liberation from international welfare. He emphasises the vital role of the ocean ecosystem to human wellbeing and in the Pacific context its important role in emancipating PICs from aid dependence through the use of their ocean resources: 64

We are a nation of water. We are a large ocean island State. We believe that given the right support we can achieve sustainable development through utilising the available resources of our vast Exclusive Economic Zone. We

62 insert footnote

63 United Nations, General Assembly, Statement by HE Ratu Inoke Kubuabola, Minister of Foreign Affairs and International Cooperation of the Republic of Fiji, General Debate of the High Level Segment of the $67^{\text {th }}$ United Nations General Assembly (28 September 2012), at 2

64 United Nations, General Assembly, Statement by HE Anote Tong, President of the Republic of Kiribati, at the General Debate of the $67^{\text {th }}$ Session of the United Nations General Assembly (26 September 2012), at 5 . 
believe that through this we can reduce our reliance on development assistance. I am convinced that we may even be able to do away with development assistance altogether, if we are provided with the support we need now to develop our capacity to harvest and process our own resources (...)

Our message to the international community is that conservation of biodiversity and marine ecosystems in the Pacific is not only important to the sustainable development of Pacific peoples; it is of vital importance to the rest of the world. The international community needs to support these efforts, not as a hand-out but as an investment for this planet's future generations.

A review of the role of PIC Ambassadors to the United Nations demonstrated capacity challenges undermined the ability of these diplomats to adequately operate in United Nations forums and found their role was marginal in these processes. ${ }^{65}$ Therefore PICs' continuing work with the broader group of global SIDS and other interested States was important to realize a joint vision for an Ocean SDG. In 2013, the joint vision for an Ocean SDG was presented at the $68^{\text {th }}$ session of the UNGA, when Navinchandra Ramgoolam, Prime Minister of Mauritius, articulated a global vision for the future of the oceans that preserves health of the oceans while expanding the economic potential of the oceans for sids. ${ }^{66}$

To gain political support in the UN for a stand-alone SDG the PICs were successful in building a broader coalition with the Alliance of Small Island States (AOSIS) recognising the imminent threat to oceans from human impacts and the importance of the oceans to their development. ${ }^{67}$ As Chair of AOsis at the time UN Permanent Representative for Nauru, Marlene Moses, made a statement emphasising the importance of ocean health as the basis for sustainable development and sought international support for an SDG that would aid SIDS in realizing their aspirations in the global economy through the preservation and development of their own ocean resources. ${ }^{68}$ Support for an Ocean SDG

65 K. McNamara, 'Voices from the Margins: Pacific Ambassadors and the Geopolitics of Marginality at the United Nations', (2009) 50:1 Asia Pacific Viewpoint, 1-12, at 10.

66 United Nations, General Assembly, Statement by Dr The Hon Navinchandra Ramgoolam, Prime Minister of the Republic of Mauritius, at the General Debate of the $68^{\text {th }}$ Session of the United Nations General Assembly (28 September 2013), at 6-7.

67 Ahmed Sareer, Statement to the United Nations on behalf of the Alliance of Small Island States (AOSIS), at the Stocktaking Session for the Intergovernmental Negotiations on the post-2015 Development Agenda (19 January 2014), at 2.

68 Statement delivered by HE Ambassador Marlene Moses, Permanent Representative of Nauru to the United Nations, Chair of Alliance of Small Island States (AOSIS), at the $6^{\text {th }}$ Session of 
by this broader coalition is nuanced; there is agreement that oceans should feature prominently under the SDGs yet hesitance to make an explicit call for a stand-alone Ocean SDG. The coalition asked only for the consideration of an ocean-themed SDG by the OWG.

The OWG on SDGs provided a direct opportunity for influence by the PICs. The constituency-based system of balanced geographical representation on the owg included three PICs: Nauru, Palau and Papua New Guinea. ${ }^{69}$ In a firm show of solidarity, twelve PICs together with Timor Leste hosted the side event "The case for a stand-alone Sustainable Development Goal on Oceans and Seas: Healthy, Productive and Resilient Oceans and Seas-Prosperous and Resilient Peoples and Communities' at the $8^{\text {th }}$ OWG on Oceans and Seas session on SDGs in February 2014; their efforts were supported by the Intergovernmental Oceanographic Commission of UNESCO and the Global Ocean Forum. ${ }^{70}$

The event was complemented by a second side event to raise the profile of ocean sustainability hosted by Italy and Palau 'Healthy Oceans and Seas: a way forward' together with the Sustainable Oceans Alliance and the Global Partnerships Forum. ${ }^{71}$ The direct outcome of these efforts was captured in the co-chairs' summary of the $8^{\text {th }}$ OWG on Oceans and Seas session on SDGs, which affirmed the importance of the role of the ocean in the post-2015 era: 'Healthy, productive and resilient oceans are important for poverty eradication, global food security, human health, climate regulation, and the creation of sustainable livelihoods and decent jobs. ${ }^{72}$

The PIC's campaign for a stand-alone Ocean SDG from the owG was successful. ${ }^{73}$ Goal 14 aims to 'Conserve and sustainably use the oceans, seas and marine resources for sustainable development' measured by seven targets. The

the OWG-SDG on the Needs of Countries in Special Situations (SIDS) (10 December 2013), at 4 .

69 United Nations, General Assembly, Open Working Group of the General Assembly on Sustainable Development Goals, A/67/L.48/Rev.1 (15 January 2013), at 2.

70 Psids, et al, 'Towards a Sustainable Development Goal (SDG) on Oceans and Seas: Healthy, Productive and Resilient Oceans and Seas - Prosperous and Resilient Peoples and Communities' (Side Event to the $8^{\text {th }}$ Session of the Open Working Group (owG) on Sustainable Development Goals (SDGs), New York, 3 February 2014), at 1-5.

71 SoA, et al, 'Healthy Oceans and Seas: A Way Forward' (Side Event to the $8^{\text {th }}$ Session of the Open Working Group (owg) on Sustainable Development Goals (SDGs), New York, 4 February 2014), at 1-3.

72 OWG, 'Co-Chairs' Summary Bullet Points for owg- 8 ' ( $8^{\text {th }}$ Session of the Open Working Group on Sustainable Development Goals, New York, 3-7 February 2014), at 1.

73 United Nations, General Assembly, Report of the Open Working Group of the General Assembly on Sustainable Development Goals, A/68/970 (12 August 2014). 
UNGA subsequently decided the owG's seventeen proposed SDGs would form the basis of integrating the SDGs into the post-2015 development agenda along with continuing inputs in the intergovernmental process. ${ }^{74}$

At the Forum Officials Committee 2014 Pre-Forum Session the PIC leaders were focused on building support for an Ocean SDG at the subsequent United Nations Conference on Small Island Developing States held in Samoa in September 2014. ${ }^{75}$ Palau's timely hosting of the 2014 Forum was opportune for PIC ocean diplomacy with an annex to the formal Forum outcome document to improve accountability for development and ocean sustainability. ${ }^{76}$ The annex to the Palau Declaration on 'The Ocean: Life and Future' Charting a Course to Sustainability constitutes a unique intervention from the region to the UN and was intended to contribute to the global effort to support a 'comprehensive, effective and implementable stand-alone Oceans Sustainable Development Goal and to the preservation of our Pacific Ocean. ${ }^{77}$ The UNSG subsequently stated his full support for the Forum's Palau Declaration that Pacific Leaders are the stewards of the Pacific Ocean. ${ }^{78}$

The Forum outcome document the Forum Communique itself documents the active campaign to the $\mathrm{UN}$ in the post-2015 development process at the UN and encourages and commends the work to date by PICs: ${ }^{79}$

Leaders reiterated the importance of member countries playing an active role in shaping the Post-2015 Development Agenda, particularly the Sustainable Development Goals (SDGs). They warmly commended and support the active efforts of Pacific Ambassadors/Permanent Representatives to the United Nations in New York to shape the Post-2015 Development Agenda, particularly the Troika of Papua New Guinea, Palau and Nauru representing the Pacific region on the sDgs Open Working Group.

Central to the strategy is the regional solidarity for improved oceans governance which has strengthened the PICs' championing of an Ocean SDG in international fora. Reflecting on the importance of solidarity, Tuvalu's Prime Minister Enele Sopoaga states that: 'the main idea is to continue to be on the same

74 United Nations, General Assembly, Report of the Open Working Group on Sustainable Development Goals established pursuant to General Assembly Resolution 66/288, A/REs/68/309 (12 September 2014), at 1. Islands Forum Secretariat, 2-3 July 2014), at 1.

76 PIFSa, supra note 47 , at 1 .

77 Ibid, at 3 .

78 United Nations, Secretary General, supra note 48.

79 PIFSa, supra note 47 , at 3 . 
canoe and use leverage to voice our concerns, unique concerns, to the wider forum membership and of course to the wider international community' 80

The Third International Conference on Small Island Developing States broadly reflected this solidarity. The PIFs Secretary General, Tuiloma Neroni Slade, presented the PICs' efforts for sustainable ocean development under the Framework for a Pacific Oceanscape and underlined the high-level commitment for an Ocean SDG from the PICs. ${ }^{81}$ An earlier sIDs interregional preparation meeting for the conference recognised sids as Large Ocean Island States and supported a stand-alone ocean SDG, ${ }^{82}$ and was referenced in the conference outcome document Small Island Developing States Accelerated Modalities of Action (Samoa Pathway). ${ }^{83}$ However, resistance from some states outside Oceania to a stand-alone Ocean SDG at the Third International Conference on Small Island Developing States meant the strong language that had typified the PIC campaign was not translated into the Samoa Pathway nor was an explicit call for an Ocean SDG made by all SIDS in this outcome document. ${ }^{84}$ This indicates that the Pacific sids form a distinct group within the United Nations SIDS in their diplomacy for an Ocean SDG.

The UNGA $69^{\text {th }}$ session theme for the General Debate 'Delivering on and Implementing a Transformative Post-2015 Development Agenda' marked a bold departure from the previous conciliatory tone of PICs in their formal diplomatic interventions on an Ocean SDG at the UNGA. This is demonstrated by the strong statement from the President of Nauru, Baron Waqa who declared that the: ${ }^{85}$

(...) reckless actions of other Nations have severely undermined the marine environment that we so depend on - from excessive greenhouse gas emissions that are warming the planet and turning the seas more and

8o ABC News, 'Niue Premier Toke Talagi fed up with Pacific Islands Forum's Smaller Island States group' (27 August 2014), available at http://www.abc.net.au/news/2014-08-27/ niue-wants-to-leave-smaller-island-states-unit/5700370.

81 Tuiloma Neroni Slade, 'Plenary Statement' (Third International Conference on Small Island Developing States, 4 September 2014), at 1.

82 SIDS, 'Small Islands Developing States (sIDs) Integrated and Enabling Cooperation Framework for the Barbados Programme of Action and Mauritius Strategy for the Further Implementation Outcome of the Inter-Regional Preparatory Meeting' (Third International Conference on Small Island Developing States, Bridgetown, 26-28 August 2013), at 15 \& 29.

83 United Nations, General Assembly, Small Island Developing States Accelerated Modalities of Action (Samoa) Pathway, A/Res/69/15 (15 December 2014).

84 Ibid.

85 United Nations, General Assembly, Statement Delivered by HE the Honourable Baron Waqa $M P$, President of the Republic of Nauru, at the General Debate of the $69^{\text {th }}$ Session of the United Nations General Assembly (25 September 2014), at 2-3. 
more acidic, to irresponsible overfishing, to outright stealing fish in our waters, to dangerous pollution (the effects of which we have yet to fully comprehend).

All the while, some of the same countries responsible for the damage are also charged with assessing the wellbeing of the marine environment. How can we be confident that our interests will be protected? We, as a developing country, are constantly facing demands for greater transparency and accountability from the same actors who downplay and sometimes even cover up their own transgressions.

Finding lasting solutions to problems like these will require more resources and a level of cooperation that the international community has thus far not countenanced. It will also require us to look at the failings in the global order that somehow prevent countries like mine from accessing fair economic benefits of our own resources (...)

The current piecemeal approach - where a donor's political interests determine aid priorities - may treat symptoms (for a time) but it fails to address the underlying disease. If we want our efforts to be successful over the long-term we need to build a foundation that develops global citizens and gives them the tools they need to succeed in a global world.'

President Waqa questioned the ability of the States responsible for environmental transgressions to protect the interests of developing countries. On the post-2015 development agenda he voiced his country's frustration that aid priorities are determined by political interests and sought a paradigm shift in development to support greater agency for PICs to manage their own marine resources to achieve sustainable development.

President of Palau, Tommy E Remengesau Jr, asserted the Pacific region would fight for the foundation of Pacific livelihoods and continue their leadership in ocean conservation. With the passion and vigour that saw him awarded the UN's highest environmental leadership award, ${ }^{86}$ he called for an Ocean SDG with realistic, transparent and measurable targets. President Remengesau Jr sought a transformational shift in the use of 'earth's natural assets' and the management of the Ocean as a joint global asset of the international community:87

86 UNEP, Small Island Developing States Spotlighted in Top Global Environmental Awards, 17 November 2014, available at http://staging.unep.org/champions/news/champions-ofthe-earth-2014-tommy-remengesau-announced.asp\#sthash.EOODhO 7 N.dpbs.

87 United Nations, General Assembly, Statement by HE Tommy E Remengesau Jr, President of the Republic of Palau, at the General Debate of the $69^{\text {th }}$ Session of the United Nations General Assembly (25 September 2014), at 2. 
Through our global actions, through our partnerships between developing and developed nations and between the private and public sectors, we can achieve transformational shifts in the way we think about the use of our earth's natural assets. By recognizing the Ocean as a joint and primary asset of every citizen on our planet, we can move toward a global management of our Global Ocean Exclusive Economic Zone.

For Oceania, an Ocean SDG is a significant contribution to transform lives by departing from the terrestrial and aid for development focus of the MDGs and improving oceans governance for the wellbeing of the global community. The UNSG commended their strong position for a stand-alone Ocean SDG. ${ }^{88}$ The campaign is illustrative of a successful joint political strategy to align and identify with their common Ocean, position themselves as ocean leaders to empower their negotiations at the UN.

\section{Goal 14 and Ocean Ecosystem Integrity}

There is an urgent need to qualify development within our oceans' ecological limits. Support for defining a stand-alone Ocean SDG is manifest in the unique ecological and humanitarian threats posed by ocean degradation. The post-2015 development agenda marked a unique occasion to develop a coherent system of governance to monitor and respond to these linkages. ${ }^{89}$ Agenda 2030's Goal 14 provides a comprehensive list of targets to meet the stated goal 'to conserve and sustainably use the oceans, seas and marine resources for sustainable development' (see Annex I). An analysis of Goal 14 would be premature as the indicators for the implementation of these targets remain under negotiation. Instead we offer further consideration of approaches from existing and emerging areas of environmental law to achieve the PIC aim of preserving ecosystem integrity. ${ }^{90}$

The PIROP is underscored by the principle to preserve ecosystem integrity as driven by regional-scale ecosystem processes. ${ }^{91}$ However, despite existing

88 United Nations, Secretary General, supra note 48.

89 Steven Bernstein, et al, 'Coherent Governance, the UN and the SDGs', (2014) Post2015/ UNU-IAS Policy Brief \#4. Tokyo: United Nations University Institute for the Advanced Study of Sustainability, at 3 .

9o Bridgewater, P., Kim, R.E. and Bosselmann, K., 'Ecological Integrity: A Relevant Concept for International Environmental Law in the Anthropocene?' (2015) 25:1 Yearbook of International Environmental Law, 61-78, at 72-75.

91 For a comprehensive introduction to the concept of ecological integrity see, PIFS, supra note 31 , at 3 \& 6 . 
obligations under the PIROP, the Ocean SDG campaign did not articulate a target to fulfil the principle for the preservation of ocean ecosystem integrity under the PIROP and neither does Goal 14 under Agenda 2030. Given preserving the ocean ecosystem is a fundamental principle of Oceania's regional oceans governance framework the omission in the PIC campaign for a corresponding target under the Ocean SDG is a lost opportunity by PICs to fulfil this regional mandate.

Kim and Bosselmann consider protection of ecological integrity a common and unifying theme in international environmental law. ${ }^{92}$ Their work integrates Rockstrom et al.'s science on the quantification of planetary boundaries critical to a safe future for humanity. ${ }^{93} \mathrm{Kim}$, Bosselman and Mauerhofer suggest addressing these interactions across scales, systems and SDG goals with an overarching goal to safeguard the ecological integrity of the earth system. ${ }^{94}$ For the SDGs Griggs et al consider this science could provide the basis for a new system of governance predicated on the protection of vital planetary systems. ${ }^{95}$

PICs show leadership for crafting a regional oceans governance framework to preserve the integrity of the oceanscape. This regional scale of governance is of importance given sub-global dynamics are critical to the ecological integrity of a functional earth system. ${ }^{96} \mathrm{Kim}$ and Bosselman consider respect for planetary boundaries could transform governance by legally limiting States' behaviour within these natural thresholds. The SDGs, while not legally binding, provided a unique opportunity for a systemic change to prevent environmental harm with ambitious goals and rigorous indicators for their achievement. The science on planetary boundaries provides some of the first specific and measurable indicators toward the achievement of the overall goal of ecological integrity. However, Loewe explains the establishment of systems for

92 R Kim and K Bosselmann, 'International Environmental Law in the Anthropocene: Towards a Purposive System of Multilateral Environmental Agreements', (2013) 2:2 Transnational Environmental Law, 285-309, at 286.

93 Johan Rockström, et al, 'A Safe Operating Space for Humanity', (2009) 461 Nature, 472-475, at 474 .

94 R Kim, K Bosselmann, and V Mauerhofer, 'Planetary Boundaries in Post-2015 Sustainable Development Goals: Safeguarding Ecological Integrity as a Priority Goal and a Grundnorm of International Law' (Discussion paper at the Planetary Boundaries Initiative 2013), at 1 .

95 D Griggs, et al, 'Sustainable Development Goals for People and Planet', (2013) 495:7441 Nature 305-307, at 305.

96 W Steffen, et al, 'Planetary Boundaries: Guiding Human Development on a Changing Planet', (2015) 347:6223 Science, 1259855 1-10, at 3. 
national accountability under the SDGs goals would likely create resistance from States. ${ }^{97}$

Palau produced an early draft for a stand-alone Ocean SDG 'to Achieve Healthy, Productive and Resilient Oceans. ${ }^{98}$ The draft Ocean SDG contains a useful structure maintaining universality, and quantifiable indicators to measure progress. The proposed justification relies, as mandated by the The Future We Want, on historical international commitments such as the 1992 Agenda 21: Programme of Action for Sustainable Development, 1992 United Nations Conference on Environment and Development and the 2002 Johannesburg Plan of Implementation of the World Summit on Sustainable Development. However, the SDGs are further mandated to be consistent with international law and build upon commitments already made ${ }^{99}$ indicating greater scope for the inclusion of binding commitments from more contemporary ocean-related Multilateral Environmental Agreements (MEA) and, fundamentally, a higher level of ambition. However, one of the outstanding outcomes of the Agenda 2030 text is the paucity of references to international law. ${ }^{100}$

Goal 14 of Agenda 2030 could be improved by setting clear specific targets integrating global ocean commitments under international law such as the Agreement for the Implementation of the Provision of the United Nations Convention on the Law of the Sea of 10 December 1982 Relating to the Conservation and Management of Straddling Fish Stocks and Highly Migratory Fish Stocks (UNFSA) ${ }^{101}$ for precautionary limits to exploitation and spatial protection targets under the Convention on Biological Diversity. ${ }^{102}$

97 Markus Loewe, 'Post 2015: How to Reconcile the Millennium Development Goals (MDGs) and the Sustainable Development Goals (SDGs)?', German Development Institute, Briefing Paper 18/2012.

98 Palau Mission to the Un, 'Toward an Ocean SDG' (Non-Paper Prepared by the Palau Mission, 17 April 2013), 1-16.

99 United Nations, General Assembly, The Future We Want, A/REs/66/288 (11 September 2012), at 47 .

100 Michelle Lim, 'Can a Systems Approach and the Sustainable Development Goals Provide A Way to Operationalise International Law for Sustainable Development to Achieve Effective Earth System Governance?' (Earth Systems Governance Conference, Canberra, 13-16 December 2015).

1011995 Agreement for the Implementation of the Provisions of the United Nations Convention on the Law of the Sea of 10 December 1982 relating to the Conservation and Management of Straddling Fish Stocks and Highly Migratory Fish Stocks, adopted 4 December 1994, 2167 UnTS 3 (entered into force 11 December 2001).

102 Sixth Ordinary Meeting of the Conference of the Parties to the Convention on Biological Diversity, Strategic Plan for the Convention on Biological Diversity, CoP 6 Decision VI/26 (7-19 April 2002). 
The greatest weakness of the Agenda 2030's Goal 14 lies in the targets that have no deadline associated to measure progress (see Annex I targets 14.3 and subtargets 14.7a and 14.7b.). Excellent guidance can be found in the Eu's Marine Strategy Framework Directive and complementary criteria for assessing the status of EU marine waters. ${ }^{103}$ Importantly, as a guide for the international SDGs, these specific and measurable indicators and targets for assessing marine ecosystems against clear targets for ecosystem health are designed for implementation by a diverse group of European States with a common and binding deadline for their achievement.

Norström et al. highlight the challenge of shifting spatial and temporal scales for the interdependence of social and ecological systems to establishing effective SDGs. ${ }^{104}$ As such traditional measures of ecosystem health may be unsuitable indicators for forthcoming ecological challenges. For example, the existing MDG measure for biodiversity uses the IUCN red list for species at risk of extinction, yet this list now encompasses criteria for threatened ecosystems. ${ }^{105}$ Members of the PIC coalition however did strive for more effective measures when Palau proposed a more ambitious indicator from the MDG measure of protected area coverage to a measure of fully protected marine areas. ${ }^{106}$

The Co-facilitators of Intergovernmental Negotiations on the Post-2015 Development Agenda acknowledged that supporting mechanisms for certain goals may need to be rearranged or even newly created to ensure effective accountability for these goals. The Pacific sIDS within the UN system were successful in creating a support mechanism to ensure the integrity of SDG14's implementation through their advocacy for the United Nations Conference to Support the Implementation of Sustainable Development Goal 14 (Conserve and Sustainably Use the Oceans, Seas and Marine Resources for Sustainable

103 Directive 2008/56/EC Of The European Parliament And Of The Council of 17 June 2008 Establishing a Framework for Community Action in the Field of Marine Environmental Policy (Marine Strategy Framework Directive), L 164/19 (25 June 2008); Commission Decision of 1 September 2010 on Criteria and Methodological Standards on Good Environmental Status of Marine Waters, L 232/14 (2 September 2010).

104 Albert Norström, et al, 'Three Necessary Conditions for Establishing Effective Sustainable Development Goals in the Anthropocene', (2014) 19:3 Ecology and Society, 81-88, at 83 .

105 Jon Paul Rodríguez, et al, 'A Practical Guide to the Application of the IUCN Red List of Ecosystems Criteria', (2015) 370:1662 Philosophical Transactions of the Royal Society B, 20140003.

106 International Institute for Sustainable Development, 'Summary of the Third Session of Intergovernmental Negotiations on the Post-2015 Development Agenda', (2015) 32:16 Earth Negotiation Bulletin. 
Development). ${ }^{107}$ The Pacific have an important role in seeing through the work they commenced for an Ocean SDG as the host of the UN Conference on Oceans and Seas in 2017. ${ }^{108}$

\section{Oceanian Ways of Seeing}

The UNSG highlighted our responsibility to act as planetary stewards in the post-2015 development process. ${ }^{109}$ This stewardship of Nature is a responsibility implicit in many of the diverse indigenous cultures of the PICs. Before colonial intervention in traditional guardianship and governance of marine resources, indigenous Polynesian societies operated at the oceanscape scale. ${ }^{110}$ Among the diverse cultures within and between PICs, however, traditional management scales were often small and locally managed. ${ }^{111}$ The scale and vision of the PIROP and FPO however demonstrate the coordinated multilateral commitment to reconcile traditional management scales with contemporary ecological challenges. When referring to the FPO Johnson et al provide the following context for PIC collaboration: ${ }^{12}$

Elsewhere, the ocean may be regarded as a barrier - isolating and separating countries from one-another, but for the Pacific Islands, the ocean plays a unifying role - bringing countries together in a common purpose. With their strong cultural and traditional ties to the ocean, and a longheld recognition that it is only through cooperation and collaboration

107 Permanent Mission of Fiji to the United Nations, Fiji Response to the Questionnaire of the Secretary-General on the Organizational Arrangements for State-Led Reviews at the High-Level Political Forum (2015), at 2.

108 United Nations, General Assembly, United Nations Conference to Support the Implementation of Sustainable Development Goal 14: Conserve and Sustainably Use the Oceans, Seas and Marine Resources for Sustainable Development, A/C.2/70/L.3/Rev.1 (2 December 2015).

109 United Nations, General Assembly, The Road to Dignity by 2030: Ending Poverty, Transforming All Lives and Protecting the Planet Synthesis Report of the Secretary-General on the Post2015 Sustainable Development Agenda, A/69/700 (4 December 2014),

110 Pierre Leenhardt, et al, 'The Rise of Large-Scale Marine Protected Areas: Conservation or Geopolitics?', (2013) 85 Ocean \& Coastal Management, 112-118, at 115.

111 R Johannes, 'The Renaissance of Community-Based Marine Resource Management in Oceania and Their Demise', (2002) 33:1 Annual Review of Ecology and Systematics, 317-340, at 317 .

112 David E Johnson, et al, 'Building the Regional Perspective: Platforms for Success' (2014) 24:S2 Aquatic Conservation: Marine and Freshwater Ecosystems, 75-93, at 80. 
that their voice will be heard on the global stage, Pacific Island states are uniquely experienced at working collectively to address shared concerns.

Hanich and Bateman also highlight the difference in world view on the oceans between States noting PICs are among the States who consider the ocean as a unifying feature that links rather than separates States. ${ }^{113}$ This way of seeing is important to understand the long history of collaboration and political solidarity that underlie their operation in the international arena. ${ }^{114}$ This suggests the perspective of the ocean as a dividing feature between these countries is a view projected from outside Oceania. This is Hau'ofa's thesis in his influential works 'Our sea of islands' and 'The ocean in us' that the oceans connect and empower a regional identity for the people of PICs as people of a common home - Oceania - a sea of islands. ${ }^{115,116}$

Hau'ofa's thesis operated to reclaim, include and unite the ancestral oceangoing people and more recent waves of migration to and from Oceania with their Pacific Ocean home as their common source of identity for solidarity. In his works Hau'ofa emphasises the vastness of PICT ocean territories as significant to the empowerment of the people of Oceania. Hau'ofa's work paralleled and followed endeavours in PIC international relations that were actively pursuing these ideas in law and policy. This idea has been the backbone of PIC diplomatic interventions on marine law and policy since efforts at UNCLOS to secure a large ocean territory and regional arrangements under the LOSC., ${ }^{117,118}$ D'Arcy considers Oceanians' reassertion of their maritime guardianship to be of global significance given the vast economic potential and relative health of Pacific marine ecosystems. ${ }^{119}$ The common Oceanian identity articulated by Hau'ofa provides motivation for their cooperation and political solidarity in oceans governance. ${ }^{120}$

\footnotetext{
113 Quentin A Hanich and Sam Bateman, 'Maritime Security Issues in an Arc of Instability and Opportunity' (2013) 9:4 Security Challenges, 87-105, at 90.

114 Michael Powles, supra note 11; David E Johnson, et al, supra note 111.

115 Epeli Hau'ofa, 'Our Sea of Islands', in Vijay Naidu, Eric Waddell, and Epeli Hau'ofa, (eds), A New Oceania: Rediscovering Our Sea of Islands (School of Social and Economic Development, The University of the South Pacific, 1993).

116 Epeli Hau'ofa, 'The Ocean in Us' (1998) 10:2 The Contemporary Pacific, 392-410.

117 Tuiloma Neroni Slade, supra note 9.

118 Michael Powles, supra note 11.

119 P D'Arcy, 'The Nourishing Sea: Partnered Guardianship of Fishery and Seabed Mineral Resources for the Economic Viability of Small Pacific Island Nations', (2013) 5:8 Sustainability, $3346-3367$, at 3346 .

120 Epeli Hau'ofa, supra note 115.
} 


\section{Conclusion}

The PICs were successful in their campaign for the inclusion of a stand-alone Ocean SDG under Agenda 2030 to improve the governance of the oceans essential to their development. Their campaign reshaped the terrestrial focus of the MDGs to enhance governance of the ocean's vital role to human wellbeing. The PICs' leadership as ocean stewards is evident in their pioneering regional oceans governance arrangements and active diplomatic interventions and coalition building for an Ocean SDG at the UN.

The PICs are leaders in their collaboration at the ocean scale - their PIROP and FPO are innovative in their accord between the jurisdictional scale of the governance system and the ecosystems they govern. The PIC campaign is a regional effort to meet the transnational challenge of managing global marine resources, like the Pacific tuna fishery, under Agenda 2030. While globalization has contributed to the erosion of PICs' sovereign rights to safeguard their marine resources, the Ocean SDG has the potential to empower PICs' governance of their marine natural resources and alleviate aspects of their deprivation. We have shown that improving oceans governance is also considered a key instrument for their empowerment and liberation from development dependence.

The PIC campaign for a stand-alone Ocean SDG at the UN provides evidence of a coordinated and effective regional foreign policy for improved oceans governance. Their strategy reframes perceptions of PICs by powers outside their region through their empowering re-identification from sIDS to LOIS. We show how the Pacific Ocean is viewed as a unifying feature that motivates the political solidarity between PICs for the stewardship of their common ocean.

In this article we have demonstrated how advocacy by PICs at the UN for the Ocean SDG operates within their natural alliances with sIDS and Forum members yet forms a distinctly strong position. The campaign represents a strengthening of collective diplomacy on ocean issues that we propose forms a distinctive brand of ocean diplomacy. The successful legacy of this collective oceans diplomacy depends on their solidarity and credibility through continued leadership in global oceans governance to empower their negotiations at the UN. 


\section{ANNEX I: The Text of Goal 14 in Transforming Our World: The 2030 Agenda for Sustainable Development}

Goal 14. Conserve and sustainably use the oceans, seas and marine resources for sustainable development

14.1 By 2025, prevent and significantly reduce marine pollution of all kinds, in particular from land-based activities, including marine debris and nutrient pollution

14.2 By 2020, sustainably manage and protect marine and coastal ecosystems to avoid significant adverse impacts, including by strengthening their resilience, and take action for their restoration in order to achieve healthy and productive oceans

14.3 Minimize and address the impacts of ocean acidification, including through enhanced scientific cooperation at all levels

14.4 By 2020, effectively regulate harvesting and end overfishing, illegal, unreported and unregulated fishing and destructive fishing practices and implement science-based management plans, in order to restore fish stocks in the shortest time feasible, at least to levels that can produce maximum sustainable yield as determined by their biological characteristics

14.5 By 2020, conserve at least 10 per cent of coastal and marine areas, consistent with national and international law and based on the best available scientific information

14.6 By 2020, prohibit certain forms of fisheries subsidies which contribute to overcapacity and overfishing, eliminate subsidies that contribute to illegal, unreported and unregulated fishing and refrain from introducing new such subsidies, recognizing that appropriate and effective special and differential treatment for developing and least developed countries should be an integral part of the World Trade Organization fisheries subsidies negotiation

14.7 By 2030, increase the economic benefits to Small Island developing States and least developed countries from the sustainable use of marine resources, including through sustainable management of fisheries, aquaculture and tourism

14.a Increase scientific knowledge, develop research capacity and transfer marine technology, taking into account the Intergovernmental Oceanographic Commission Criteria and Guidelines on the Transfer of Marine Technology, in order to improve ocean health and to enhance the contribution of marine biodiversity to the development of developing countries, in particular small island developing States and least developed countries 
14.b Provide access for small-scale artisanal fishers to marine resources and markets

14.c Enhance the conservation and sustainable use of oceans and their resources by implementing international law as reflected in UNCLOS, which provides the legal framework for the conservation and sustainable use of oceans and their resources, as recalled in paragraph 158 of The Future We Want. 